\title{
O governo das águas: o sistema de abastecimento hídrico na Cidade de Goiás na primeira metade do século $\mathrm{XX}^{1}$
}

\section{Water government: the water supply system in the City of Goiás in the first half of the 20th century}

\author{
Fernando Lobo Lemes* \\ https://orcid.org/0000-0002-0547-0613 \\ Pedro Henrique Pereira* \\ https://orcid.org/0000-0001-5303-4579
}

\begin{abstract}
Resumo
Este artigo analisa o processo de modernização da Cidade de Goiás, durante a primeira metade do século XX, propõe uma análise das práticas políticas associadas ao controle da água e acompanha algumas reflexões importantes para o conhecimento e a compreensão do movimento de implantação do sistema de distribuição de água na cidade, interligado ao discurso modernista e à retórica higienista. A experiência dos protagonistas nos procedimentos de canalização da água indicava a necessidade de domesticá-la, transportá-la por novas vias, disciplinar os homens, redefinindo normas e obrigações. Neste contexto, foram problematizadas as estratégias adotadas pelo governo da cidade para fazer frente ao processo de apropriação e controle da água, tendo em vista a construção de redes subterrâneas de abastecimento ligando mananciais e reservatórios aos espaços privados de uso doméstico. A partir deste problema central, tratou-se de investigar o nascimento de uma nova forma de uso da água, associada a estratégias que envolvem procedimentos de gestão associados a programas capitaneados pelos poderes municipais. A leitura e interpretação de documentos inéditos disponíveis no Arquivo Histórico Frei Simão Dorvi, da Cidade de Goiás, norteou o desenvolvimento da pesquisa.

Palavras-chave: Gestão da Água. Sistema de Abastecimento. Cidade de Goiás.
\end{abstract}

\footnotetext{
${ }^{1}$ Este artigo é resultado parcial de pesquisa realizada no Programa de Pós-Graduação em Territórios e Expressões Culturais no Cerrado (TECCER) da Universidade Estadual de Goiás (UEG) e no Programa de Iniciação Científica do Curso de Direito da Faculdade Evangélica Raízes e contou com o apoio financeiro da Fundação de Amparo à Pesquisa do Estado de Goiás (FAPEG).

*Doutor em História pela Université de la Sorbonne Nouvelle - Paris 3, professor do Programa de PósGraduação Stricto Sensu Territórios e Expressões Culturais no Cerrado (TECCER) da Universidade Estadual de Goiás (UEG) e coordenador do Núcleo de Pesquisa Científica (NPC) do Curso de Direito da Faculdade Evangélica Raízes. E-mail: fernando.lemes@ueg.br

${ }^{* *}$ Mestre em Ciências Sociais e Humanidades pelo Programa de Pós-Graduação Stricto Sensu Territórios e Expressões Culturais no Cerrado (TECCER) da Universidade Estadual de Goiás (UEG) e professor no Centro Estadual de Educação de Período Integral Padre Trindade. E-mail: pedro_henriquephp@hotmail.com
} 


\begin{abstract}
this article analyzes the modernization process of the City of Goias during the first half of the 20th century, proposes an investigate about the political practices associated with water control and follows some important notions for the knowledge and understanding of the movement of implementation of the water supply system in the city, interconnected to modernist discourse and hygienist rhetoric. The experience of the protagonists in the procedures of water channeling indicated the need to transport by new ways redefining norms and obligations. In this context, the strategies adopted by the city government to deal with the process of appropriation and control of water, with a view to the construction of underground supply networks connecting water sources and reservoirs to private spaces for domestic use were problematized. Based on this central problem, it was investigated the birth of a new form of water use, associated with strategies involving management procedures associated with municipal powers. The reading and interpretation of unpublished documents available in the Frei Simão Dorvi Historical Archive, in the City of Goias, guided the development of research.
\end{abstract}

Keywords: Water Management. Supply System. City of Goiás.

\title{
Introdução
}

A história do abastecimento de água nas sociedades humanas possui uma longa história. Desde a Antiguidade, a necessidade de seu consumo proporcionou o surgimento de invenções que pudessem transportar a água de um local para outro. Da mesma forma, o próprio crescimento urbano está associado às formas como as cidades eram capazes de se abastecer e distribuir este recurso para sua população.

Como lembra Bruni, ${ }^{2}$ a água é vida. Sua presença é constante e diária nas sociedades humanas. ${ }^{3}$ De acordo com Sant'Anna, ${ }^{4}$ ao abrirmos as torneiras

\footnotetext{
${ }^{2}$ BRUNI, José Carlos. “A água e a vida”. Revista Tempo social, v. 5, n. 1-2, p. 53-65, 1993.

${ }^{3}$ Este autor trata a água e sua utilização como algo comum e cotidiano nas sociedades humanas. Considera, portanto, o abastecimento de água como fenômeno banal. Ao citar o processo de implantação de encanamentos em uma cidade francesa, por volta de 1950, Roche aborda a transformação técnica da forma de se obter a água como atividade também social, na qual ocorrem mudanças de gestos e hábitos, como o simples ato de abrir e fechar uma torneira. ROCHE, Daniel. História das coisas banais: nascimento do consumo nas sociedades tradicionais (XVII-XIX). Lisboa: Editorial Teorema, 1998.

${ }^{4}$ SANT’ANNA, Denise Bernuzzi. “A conquista da água”. Revista Projeto História. São Paulo, v. 18, p. 295-300, 1999.
} 
entramos em contato com uma extensa rede técnica e social de abastecimento que rompe com o limite doméstico, percorre as ruas das cidades por caminhos subterrâneos, passa por incontáveis metros de canos e reservatórios até alcançar os rios. Neste aspecto, vale mencionar que há também redes hídricas de capilaridade fluvial onde as águas urbanas são captadas em mananciais, usadas no metabolismo da cidade e descartadas novamente nos leitos dos rios, como se, de certa maneira, as pessoas e a própria cidade fossem extensões da circulação fluvial.

O abastecimento de água é, portanto, um processo que conta a história de transformações na sensibilidade de homens e mulheres na relação com a natureza e a técnica. 0 discurso quanto aos usos da água e sua preservação vem alcançando uma posição de destaque em torno de práticas mais conscientes quanto a sua utilização na atualidade.

Neste contexto, este artigo propõe uma análise das práticas políticas associadas ao controle da água e acompanha algumas reflexões importantes para o conhecimento e a compreensão do processo de modernização do sistema de distribuição de água na Cidade de Goiás, durante a primeira metade do século XX.

Quais foram os mecanismos e as estratégias adotadas pelo governo da cidade para fazer frente ao processo de apropriação e controle da água, tendo em vista a construção de redes subterrâneas de abastecimento, ligando mananciais e reservatórios aos espaços privados de uso doméstico? A partir deste problema central, trata-se de investigar o nascimento de uma nova forma de uso da água, associada a estratégias que envolvem instituições, aspectos jurídicos e medidas de gestão associadas a programas capitaneados pelos poderes locais, sobretudo, o Poder Executivo e a Câmara Municipal.

Capital regional durante cerca de 200 anos, a Cidade de Goiás ainda convivia, em meados do século XX, com o transporte rudimentar da água para o consumo doméstico. Dentre os métodos utilizados, a imagem tradicional das "latas d'água" - trabalho realizado por mulheres que, equilibristas, transportavam latas nas cabeças desde os chafarizes e bicas até as residências - indicava uma arraigada tradição e forte conexão com o passado. Neste ambiente, a apreciação da água como produto e aspecto da vida ligado ao conforto, aventada nos documentos da época, parecia apenas uma ideia distante. Entretanto, captada gratuitamente nos mananciais públicos, a prática de se cobrar um valor pecuniário pela água tomou vulto nos anos 1940 e - como descreve Bosi a propósito da instalação do primeiro serviço coletivo de água 
em Uberabinha, antiga Freguesia de Uberaba - "converteu-se em uso privado, medido e intermediado pela torneira". ${ }^{5}$

Na Cidade de Goiás, se a água domesticada, constrangida através de canos submersos, é posta a serviço dos homens, subverte e desafia, ao mesmo tempo, os seus poderes. Ali, entre o governo dos homens e a domesticação da natureza, a trajetória das águas do Rio Bacalhau às redes domésticas de abastecimento pode revelar uma história que ainda não foi contada.

\section{Promessas e expectativas de uma cidade moderna: o discurso sobre a canalização subterrânea da água}

Os avanços tecnológicos associados ao processo de modernização da região - a exemplo da implementação da ferrovia que ligava o sul do Estado de Goiás a importantes cidades do sudeste brasileiro - estimulavam transações econômicas e alteravam as relações de força entre os poderes políticos regionais. Neste contexto, a situação da capital, a Cidade de Goiás, sofria os impactos negativos das mudanças, tornando-se objeto de disputa e alvo de ataques dos grupos que articulavam em seus discursos princípios e valores conectados ao golpe de $1930 .{ }^{6}$ Em Goiás, a construção de Goiânia e a transferência da capital informavam a destituição das condições e vantagens ligadas à capitalidade secular do antigo centro político que, por sua vez, amargava a derrota de seus grupos e lideranças para as novas elites que chegavam ao poder.

Não é a intenção deste artigo interpretar ou compreender todos os elementos decorrentes deste acontecimento, exceto quando as críticas a respeito dos aspectos urbanos e sanitários compunham o discurso político interessado na transferência da capital (da Cidade de Goiás para Goiânia), elencando suposições quanto a qualidade da água potável, associando-a aos males provocados à saúde da população.

\footnotetext{
${ }^{5}$ BOSI, Antônio. “As águas das cidades (1850-1920): usos e negócios”. Revista História e Perspectivas, v. 1, n. 36-37, p. 109-132, 2007, p. 114.

${ }^{6}$ Revolução de 1930 foi o movimento armado, liderado pelos estados de Minas Gerais, Paraíba e Rio Grande do Sul, que culminou com o golpe de Estado de 1930 que depôs o presidente da república Washington Luís, em 24 de outubro de 1930, impediu a posse do presidente eleito Júlio Prestes e pôs fim à República Velha.

${ }^{7}$ De acordo com Chaul, a "representação da modernidade absorvida pelos arautos de 30 indicava a tentativa de rompimento com o passado e a construção de uma utopia, o vislumbre de um futuro grandioso para o estado de Goiás, por intermédio da edificação de Goiânia. Esse imaginário salvacionista, que marcou o projeto brasileiro de modernidade, apresentava-se a Goiás como a redenção de um tempo mergulhado em décadas de miséria e penúria. Neste cenário, a nação e a região se encontram unidas em um mesmo fim: a busca da modernidade através do ideal de progresso". CHAUL, Nasr Fayad. Caminhos de Goiás: da construção da decadência aos limites da modernidade. Goiânia: Editora UFG, 2001, p. 29.
} 
A modernização e o progresso eram noções presentes nos discursos dos adeptos da mudança da capital, elites políticas e econômicas que, à época, pretendiam representar a possibilidade de superação do passado, associado, desde então, à condição de atraso e a uma espécie de anti-modernidade. De acordo com Oliveira, a disputa entre aqueles que eram a favor da mudança da capital e os "antimudancistas" foi acirrada. ${ }^{8}$ Para este autor, Pedro Ludovico Teixeira ${ }^{9}$ teria justificado a necessidade da mudança com base em dois argumentos fundantes: a) a necessidade de construir uma cidade moderna que representasse e trouxesse o desenvolvimento ao Estado; e b) as péssimas condições higiênicas da Cidade de Goiás, resultado de uma antiquada arquitetura colonial.

Para Chaul, embora existissem outras justificativas implícitas no processo da mudança, o fator de peso favorável aos ideais do médico interventor nomeado pelo presidente Getúlio Vargas era a própria situação da cidade. Segundo este autor, aspectos geográficos e urbanos foram utilizados para demonstrar que as condições da cidade não permitia sustentar argumentos satisfatórios para se manter na qualidade de capital, preservando sua capitalidade. ${ }^{10}$ Em seu relatório, citado por Chaul, o interventor indicava elementos que condicionavam negativamente a situação da capital, dentre eles, o problema da água potável e o escoamento de águas servidas:

[...] d) abastecimento de água - o problema do abastecimento de água permanece insolúvel, tal como em 1890, tal como sempre. Toda água potável consumida pela população da capital é transportada na cabeça, em potes, e fornecida pelas únicas e pobres fontes existentes [...]. ${ }^{11}$

De acordo com Souza, além da arquitetura e da localização geográfica, o problema ligado à falta de água e à rede de esgotos foi um dos principais pontos utilizados por Ludovico Teixeira para desconstruir a imagem da Cidade de Goiás enquanto capital do Estado. ${ }^{12}$ Quanto ao abastecimento, o interventor

\footnotetext{
${ }^{8}$ OLIVEIRA, Eliézer Cardoso. “As tragédias como evento hermenêutico: as enchentes do Rio Vermelho na Cidade de Goiás”. Revista História e Cultura, v. 3, p. 306-324, 2014.

${ }^{9}$ Médico e interventor em Goiás, instituído no cargo por Getúlio Vargas. Desabilitou do poder oligarquias tradicionais da região promovendo, também, a mudança da capital da antiga Cidade de Goiás para Goiânia.

${ }^{10}$ CHAUL, op. cit., p. 11.

${ }^{11}$ Ibidem, p. 211.

${ }^{12}$ SOUZA, Rildo Bento de. A História não perdoa os fracos: o processo de construção mítica de Pedro Ludovico Teixeira. 2015. 269 f. Tese (Doutorado em História) - Universidade Federal de Goiás, Goiânia, 2015, p. 95.
} 
foi incisivo ao condenar as condições da oferta de água potável, até então restrita aos chafarizes. Segundo ele,

É muito comum, em todas as cidades que não têm água canalizada, o expediente primitivo de recorrer á população á abertura de cisternas para se prover de agua potavel. Nesta capital, nem desse recurso se póde valer a população, ainda que a maioria das casas tenha cisterna. É que aqui a agua de poço é absolutamente impotavel, devido á abundancia de carbonato de cálcio que lhe adicionam as rochas calcareas que formam o sub-solo da cidade. Rara é a cisterna que não se tenha aberto na pedra viva, a dinamite. Em alguns pontos centrais do perímetro urbano, as águas dos poços não são utilizadas nem para banhos, porque, além do carbonato de calcio, contêm outras substancias que as tornam viscosas, neutralizam a ação química do sabão e provocam sensação desagradavel na epiderme. ${ }^{13}$

De fato, em Goiás, toda a década de 1930 seria marcada pelos efeitos e consequências dos embates em torno da construção de Goiânia e do processo de transferência da capital, até o seu batismo cultural, em 1942. Desde então, o comportamento e a reação da população da Cidade de Goiás, agora já não mais sede de governo, aparentavam desânimo. Sobretudo, por que as esperadas inovações requeridas pelos habitantes da cidade, ainda na condição de capital, não haviam sido concretizadas, produzindo uma expectativa negativa quanto ao futuro. Agora, na condição de simples município dentre outros, o antigo desejo de implantação de um sistema de distribuição de água moderno parecia inalcançável.

Além disso, os discursos contrários à transferência da capital ampliavam essa sensação. No campo político, as insatisfações tomavam a forma de luta, indicando resistências. Neste contexto, para uma coligação de grupos contrários à transferência da capital,

A mudança arruinaria a todos [Vilaboenses]: comércio, lavradores, rentistas etc. Com a mudança a cidade iria converter-se numa tapera, em breve não seria senão um vasto cemitério de casas despovoadas. [...] votar nos candidatos da Coligação Libertadora é desagravar a Cidade de Goiás de todas as humilhações que tem sofrido. Nada de contemplações: pau nos mudancistas. ${ }^{14}$

\footnotetext{
${ }^{13}$ CHAUL, op. cit., p. 114 .

${ }^{14}$ Ibidem, p. 217.
} 
Assim, os receios inventariados pelos "antimudancistas"15 quanto aos males que ocorreriam à cidade caso deixasse de ser capital, funcionaram como um forte discurso para a Coligação Libertadora. ${ }^{16}$

Na prática, em 1932, os mesmos antigos problemas provenientes do século XIX ainda assolavam a população da Cidade de Goiás, a exemplo da falta de água nos períodos de seca e a contaminação das águas dos chafarizes, conforme pode ser percebido em ofício da Diretoria Geral do Serviço Sanitário do Estado destinado ao prefeito municipal: "Chegando ao conhecimento desta diretoria", diz o encarregado de expediente Rômulo Rocha, "que o Chafariz da Carioca está com a água infeccionada, solicita-lhe imediatas providências, precedendo (sic) a remoção de toda água em depósito". ${ }^{17}$

Da mesma forma, o destino das águas servidas ainda contribuía para a deterioração do quadro sanitário, podendo ser verificados velhos hábitos de despejo, como indica um abaixo assinado de um grupo de moradores, datado de 1935, que solicitava permissão à Câmara Municipal para abrir esgotos nos quintais de suas propriedades, despejando detritos no leito do Rio Vermelho. Pedro Ludovico Teixeira, no entanto, havia feito alusão a este tipo de procedimento. Nos termos de seu relatório,

[...] como pode uma cidade ser limpa, higiênica, habitável sem possuir um sistema de galerias subterrâneas para o escoamento dos detritos, águas servidas e materias fecais? E mais: se se realizasse a captação e canalização de agua em volume suficiente para atender as necessidades da população da cidade de Goiaz, como se poderia construir, com os parcos recursos da municipalidade, ainda que auxiliada pelo Estado, a obra complementar, no caso a rêde de esgostos, que, a ser traçada e realizada como a exigem as condições do centro urbano, imporia um dispêndio talvez superior a 2.000 contos? ${ }^{18}$

\footnotetext{
${ }^{15}$ Rildo Bento de Souza pressupõe que os que defendiam que a Cidade de Goiás precisava de reformas estruturais para se modernizar poderiam estar provavelmente inspirados nas mudanças empreendidas em Paris no século XIX (comandadas por Georges-Eugéne Haussmann) e em São Paulo e no Rio de Janeiro, no século XX. SOUZA, op. cit, p. 98.

${ }^{16}$ A coligação organizava-se em torno de movimentos baseados em duas tradicionais famílias da cidade: velasquistas e caiadistas. 0 nome Coligação mostrava a união do Partido Libertador, fundado por Velasco, e o Partido Democrata, fundado pelos Caiado. CHAUL, op. cit., p. 216.

${ }^{17}$ Ofício da Diretoria do Serviço Sanitário do Estado de Goiás ao prefeito municipal da Cidade Goiás. Goiás, 7 de novembro de 1932. Arquivo Histórico Frei Simão Dorvi (AHFSD).

${ }^{18}$ CHAUL, op. cit., p. 114.
} 
Por seu turno, a ação da Câmara Municipal se limitava a medidas paliativas para a solução dos problemas de abastecimento e da higiene, como ocorreu em 1937, quando da proibição parcial da lavagem de roupa no Córrego Manuel Gomes, por contaminar as águas que iam para as dependências do quartel, por solicitação do comandante do quartel da Polícia Militar em Goiás. ${ }^{19}$

Assim, a década de 1940 iniciava-se sob uma espécie de penumbra, um tempo de incertezas que encobria, como um véu sombrio, o destino da cidade. E o peso das transformações exercido pela construção de Goiânia era sentido profundamente nos ambientes da Cidade de Goiás.

O receio da perda dos privilégios associados à capital, centro de poder da região, poderia acabar de uma vez por todas com a possibilidade de promover a "modernização" do sistema de distribuição de água por meio de encanamentos subterrâneos, antiga expectativa da população. Neste aspecto, os primeiros anos da década mostraram-se muito semelhantes às duas décadas anteriores: o acesso à água restrito aos chafarizes, as frequentes críticas provenientes da população e a incapacidade de solução do problema por parte do poder público.

\section{Primeiros ensaios: o projeto de canalização da água nos espaços políticos da cidade}

A situação só iria de fato sofrer alterações em 1946. No dia 10 de setembro o então prefeito municipal, Divino de Oliveira, recebe um ofício no qual o diretor comercial da Goianenge (Sociedade Goiana de Engenharia) faz referência a uma carta resposta à solicitação de um orçamento a respeito de um projeto de canalização de água para a cidade. Assim, a empresa, com sede em Goiânia, propunha o valor de Cr\$15.000,00 cruzeiros para realização de estudo e projeto de provimento por água encanada, possibilitando o pagamento em até três parcelas. ${ }^{20}$

Sem resposta do município, em 25 de setembro a mesma empresa encaminha outro documento indagando se o estudo realizado ainda era de interesse do chefe do Poder Executivo municipal, sugerindo ao prefeito que recorresse a Berlamino Cruvinel - nomeado pelo presidente da República como interventor no Estado de Goiás (de 12 de setembro de 1946 a 22 de

\footnotetext{
${ }^{19}$ Ofício do comandante do quartel da Polícia Militar do Estado de Goiás ao prefeito municipal da Cidade de Goiás. Goiânia, 29 de maio de 1937. Arquivo Histórico Frei Simão Dorvi (AHFSD).

${ }^{20}$ Ofício do diretor comercial da Sociedade Goiana de Engenharia ao prefeito municipal da Cidade de Goiás. Goiânia, 10 de setembro de 1946. Arquivo Histórico Frei Simão Dorvi (AHFSD).
} 
outubro de 1946) - "para conseguirvos uma aprovação expressa do Governo para a execução do serviço pelo sistema de administração". ${ }^{21}$

Divino de Oliveira, por sua vez, encaminha dois ofícios ao Diretor do Departamento das Municipalidades, Abel Soares de Castro. 0 primeiro, de 28 de setembro, solicitava, por meio de uma exposição de motivos, um empréstimo para financiar o estudo e um projeto para a implementação do abastecimento de água da cidade. No seu primeiro item, dizia o seguinte:

A Cidade de Goiáz comemorou no último 26 de julho passado, seu duzentessimo decimo novo aniversario de fundação, e tristemente, o fez com toda rotina, assistindo percorrer suas ruas, de potes à cabeça as suas já célebres "aguadeiras", mulheres que vivem de levar às casas algumas latas dagua com que se atende todos os misteres domésticos, inclusive banho, cozinha, higiene, etc. É doloroso para o mundo moderno assistir ao quadro que retrata uma época de há tanto relegada por outros municípios brasileiros. ${ }^{22}$

A descrição do prefeito de fato correspondia às condições observadas no cotidiano da cidade, onde ainda permaneciam vivas as antigas atividades ligadas ao uso e ao transporte da água, como as lavadeiras e aguadeiros, que configuravam um aspecto simbólico da vida dos habitantes. Atividades tradicionais na história da cidade que, como indica Monteiro, ocorriam em meio às dificuldades estruturais ligadas ao ambiente urbano em expansão. Segundo o autor,

Os mananciais que abasteciam os chafarizes da cidade, quase secos, faziam diminuir a quantidade do precioso líquido nas bicas. 0 tênue fio de água das torneiras custava a encher um pote. Resultado: grande número de aguadeiros se acumulava nas proximidades do chafariz da Praça resultando discussões, brigas, vias de fato. ${ }^{23}$

A esse respeito, a observação mordaz no relatório de Ludovico Teixeira soa como pesada denúncia que associava dois problemas tradicionais vividos pela população da cidade. Segundo ele,

\footnotetext{
${ }^{21}$ Ofício do diretor comercial da Sociedade Goiana de Engenharia ao prefeito municipal da Cidade de Goiás. Goiânia, 25 de setembro de 1946. Arquivo Histórico Frei Simão Dorvi (AHFSD).

${ }^{22}$ Ofício do prefeito municipal ao diretor do Departamento Estadual das Municipalidades. Goiás, 28 de setembro de 1946. Arquivo Histórico Frei Simão Dorvi (AHFSD).

${ }^{23}$ MONTEIRO, Ofélia Sócrates do Nascimento. Reminiscências: Goiás de antanho. 1907 a 1911. Goiânia: Oriente, 1974, p. 30.
} 
[...] tendencia comum, verificável em muitas famílias goianas, de manter cada uma delas um bôbo - mentecapto, idiota, imbecil - para o serviço de transportes domésticos, especialmente o de agua. Com isso, existem "numerosas famílias que se beneficiam dos serviços desses desherdados da sorte, transformando-os em escravos irremissiveis, a troco dos restos de comida e de um canto para dormir, não raro entre os animais. ${ }^{24}$

As palavras de Souza confirmam a afirmação do interventor: “[...] com isso", afirma o autor, "surge o problema dos carregadores de água, formados, principalmente, por pessoas com problemas neuropsicológicos". Na verdade, ao utilizar o discurso de Ludovico Teixeira sobre o abastecimento através de fontes e chafarizes, o autor condena os ofícios ligados ao uso e transporte de água, parecendo indicar que este ofício e atividade estaria reduzido aos "doentes mentais", aos deserdados da sorte, ignorando a tradicional figura feminina, responsável por esse serviço: exemplo de invisibilização do trabalho realizado pelas mulheres. ${ }^{25}$ De fato, esta atividade não era exclusiva das mulheres, mesmo porque não eram todos que podiam pagar pelo serviço. Contudo, o tom verificado na narrativa do autor é o mesmo ao tratar de todo o cenário que envolvia a Cidade de Goiás: de condenação.

A profissão das carregadeiras, portanto, permaneceu por séculos, não somente em função da tradição, mas, sobretudo, pelas imposições de um sistema hídrico limitado e incapaz de atender à demanda proveniente das dimensões ampliadas da cidade em meados do século XX.

Segundo Albernaz,

A cidade não tinha infra-estrutura e a água das cisternas, por ser salobra, só era utilizada nas lides domésticas; água para se beber tinha que ser dos chafarizes, preferentemente a da Carioca, por ser mais potável. Os carregadores de água, em potes ou latas equilibrados sobre a cabeça, faziam deste trabalho profissão estável. ${ }^{26}$

No decorrer da exposição de motivos a Soares de Castro, o prefeito municipal, ao se dizer inconformado com esta "rotina" de carregadores de água por toda a cidade, afirma que a melhoria das condições econômicas pela qual passava a cidade permitirá, finalmente, a modernização do abastecimento de água, tão perseguida por seus antecessores:

\footnotetext{
${ }^{24}$ CHAUL, op. cit., p. 115 .

${ }^{25}$ SOUZA, op. cit., p. 95.

${ }^{26}$ ALBERNAZ, Ondina de Bastos. Reminiscências. Goiânia: Kelps, 1992, p. 30.
} 
Desta vez, porém, apelo para o Departamento das Municipalidades, para o Conselho Administrativo, para solicitar-lhes que, amparando esse ideal, filho duma necessidade premente, deem preferencia a este meu processo [...]. O Sr. General Xavier de Barros, ao tempo de elaboração do projeto, interventor em nosso Estado, apoia inteiramente a ideia e prometeu todo o seu apoio. Sei que o atual Interventor, Dr Belarmino Cruvinel, terá prazer em amparar esta minha pretensão, que é velha aspiração do povo da velha Capital. ${ }^{27}$

A mesma crítica aos aguadeiros também fora impressa no segundo ofício, enviado em 10 de outubro do mesmo ano. De acordo com Divino de Oliveira, "embora envergonhados do quadro deprimente das 'aguadeiras' que se enfileiram à beira dos poços e chafarizes da cidade, ninguém tomou a peito realizar a obra de construção da rede dagua para Goiaz". ${ }^{28}$ Entretanto, neste ofício, o prefeito parece mais disposto a explicar a situação da cidade após o período da transferência da capital. Entre os avanços nos quadros urbanos de Goiás, cita o aumento da população para seis mil habitantes, somente no núcleo urbano, e a renda municipal que, atingindo a cifra de $\operatorname{Cr} \$ 1.000 .000,00$, seria "superior ao tempo em que era capital (Cr\$400.000,00)". Além disso, destaca a ampliação do comércio e da indústria, o que, em suas palavras, significa que a economia jamais regredirá.

De fato, suas súplicas foram ouvidas e o prefeito obteve provimento legal e permissão para efetuar o empréstimo de quinze mil cruzeiros. Estavam lançadas as cartas para o pontapé inicial na execução de um projeto definitivo de abastecimento de água para a cidade. Assim, foi feito o pagamento pela realização do projeto a Oton Nascimento, engenheiro e diretor técnico da Sociedade Goiana de Engenharia, a Goianenge.

Em seguida, em 17 de maio de 1947 é publicado no Diário Oficial do Estado um edital de concorrência pública para a execução das obras de abastecimento de água encanada na Cidade de Goiás. ${ }^{29}$ No entanto, ao final do prazo previsto apenas uma empresa havia manifestado interesse: a própria Goianenge.

\footnotetext{
${ }^{27}$ Ofício do prefeito municipal ao diretor do Departamento Estadual das Municipalidades. Goiás, 28 de setembro de 1946. Arquivo Histórico Frei Simão Dorvi (AHFSD).

${ }^{28}$ Ofício do prefeito municipal ao diretor do Departamento Estadual das Municipalidades. Goiás, 10 de outubro de 1946. Arquivo Histórico Frei Simão Dorvi (AHFSD).

${ }^{29}$ Proposta da diretoria da Goianenge para execução do serviço de água potável para a Cidade de Goiás. Goiânia, 29 de julho de 1947. Arquivo Histórico Frei Simão Dorvi (AHFSD).
} 
Em 29 de julho, contendo quatorze laudas, é enviada ao prefeito municipal de Goiás a proposta detalhada para a execução do serviço organizada em cinco tópicos: 1 - tomada d'água; 2 - linha adutora; 3 - reservatório de distribuição; 4 - rede de distribuição; 5 - chafariz..$^{30}$

A captação da água ocorreria por meio das águas do córrego Bacalhau, a uma altura de 23 metros acima do nível geral da cidade, permitindo abastecimento por gravidade, onde uma barragem deveria ser construída em alvenaria de pedra argamassada com cimento e areia. ${ }^{31}$

A linha adutora canalizaria a água da represa até a caixa de areia, que serve para reter qualquer material que possa entupir ou obstruir a passagem da água, sendo construída em alvenaria de tijolos, mesmo material utilizado no canal. Toda a linha adutora, da caixa de areia às câmaras de decantação, seria feita de manilhas de concreto, com exceção do sifão a ser utilizado, dotada de sessenta poços de inspeção com tampas de ferro fundido. As travessias das depressões e gargantas seriam feitas de concreto armado e, na travessia da última depressão antes de chegar ao reservatório, um sifão de 134 metros de comprimento.

O reservatório fora calculado para ser capaz de armazenar $625 \mathrm{~m}^{3}$ de água, correspondente a $26 \%$ do consumo total, correspondendo a 2.400 .000 litros diariamente, incluindo abastecimento futuro para uma população de 12 mil habitantes. A proposta inicial consistia na construção de dois reservatórios e, mais tarde, quando a necessidade exigisse, se duplicaria seu número. ${ }^{32}$

Quanto à rede de distribuição, segundo o mesmo relatório, “[...] será feita por canos de ferro de diversos diâmetros conforme o projeto indicando as diversas zonas da cidade. Este plano da distribuição foi bem estudado, cuidando já um futuro aumento da população". ${ }^{33}$

Finalmente, seria destinado ao chafariz da Praça Pinheiro Machado um encanamento de água. Essa tentativa de aumentar o volume da água dos chafarizes cumpriria uma outra função: abastecer por meio de encanamentos alguns estabelecimentos municipais e privados. A última parte do projeto trataria de expor um resumo geral dos gastos para a implantação do serviço de água encanada da Cidade de Goiás, cujo valor somaria a vultosa quantia de

\footnotetext{
${ }^{30}$ Parecer [de Goiás do Couto, Fritz Koeller e Humberto Rizzo] sobre proposta para a execução dos serviços de abastecimento de água potável. Cidade de Goiás, 4 de agosto de 1947. Arquivo Histórico Frei Simão Dorvi (AHFSD).

${ }^{31}$ Idem.

${ }^{32}$ Idem.

${ }^{33}$ Idem.
} 
Cr\$3.219.664,40, além de mais Cr\$72.000,00 anualmente para despesas com operários e manutenção.

Baseando-se no projeto apresentado, os técnicos da Goianenge solicitaram um prazo de 24 meses para a realização das obras, após a assinatura do contrato. De outra parte, por se tratar da única proposta recebida durante o período de vigor do Edital, o prefeito logo ordenou que fosse feito um estudo econômico para analisar as formas de pagamento.

Em 2 de setembro de 1947, o prefeito municipal João J. Coutinho encaminha ao Diretor do Departamento das Municipalidades, José de Assis de Moraes, o decreto-lei que autorizava a realização das despesas necessárias para consecução da obra, acompanhado de uma exposição de motivos, do estudo econômico e da proposta apresentada pela Goianenge, empresa ganhadora da concorrência. ${ }^{34}$

Na exposição de motivos, Coutinho lembra das tentativas de seus antecessores e, principalmente, daqueles que acreditavam na impossibilidade de uma solução para o grave problema de abastecimento de água na cidade e adverte a respeito do valor previsto no orçamento, cujo “[...] preço apresentado - Cr\$3.219,644,40 - não se nos afigura elevado, máxime-se levar em conta a composição rochosa do nosso terreno, de difícil escavação". ${ }^{35}$ Afirma também que, no estudo econômico anexado aos documentos, a proposta seria ofertar água a 1.600 imóveis, ao preço mensal de $\mathrm{Cr} \$ 28,00$ para cada unidade residencial, e compara este valor ao preço médio cobrado pelas lavadeiras. Em suas palavras,

[...] esse preço não se nos afigurou de maneira alguma excessivo, se se considerar que toda casa, nesta cidade, gasta uma média de $\operatorname{Cr} \$ 15,00$ a $\operatorname{Cr} \$ 40,00$ por mês, exclusivamente no transporte de agua apanhada nos Chafarizes. Ademais, o liquido assim obtido destina-se somente às necessidades orgânicas dos componentes de cada casa, não sendo utilisada na cosinha, e banho, onde o consumo seria muito maior. Pelo preço de $\mathrm{Cr} \$ 28,00$ por prédio, terá cada família a agua exigida para todas as suas necessidades, quer de bebida, banho, cosinha, como de irrigamento de jardim, lavagem de roupa, etc. ${ }^{36}$

\footnotetext{
${ }^{34}$ Ofício do prefeito municipal da Cidade de Goiás, João Coutinho, ao diretor do Departamento Estadual das Municipalidades, José de Assis Moraes. Goiás, 2 de setembro de 1947. Arquivo Histórico Frei Simão Dorvi (AHFSD).

${ }^{35}$ Idem.

${ }^{36} \mathrm{Idem}$.
} 
Para a obtenção do empréstimo, o município deveria negociar com alguma instituição de crédito, como a Caixa Econômica Federal, Companhia de Capitalização ou de Seguros ou empresa de qualquer natureza, "tendo em vista a idoneidade de cada uma e a que melhores vantagens oferecer" ${ }^{37}$.

Quantos às condições do pagamento, Coutinho lembra que,

A amortização do capital far-se-á a partir do quarto ano, mediante o resgate, pelo seu valor nominal, das obrigações que forem sorteadas na primeira quinzena de Março ou Setembro de cada ano, ficando o empréstimo totalmente liquidado no prazo de vinte anos, [...] a juros de $8 \%$ ao ano, pela Tabela Price. (Grifo dos autores). ${ }^{38}$

A proposta também fora enviada ao então governador de Goiás, Jerônymo Coimbra Bueno, que apoiou o projeto e também o empréstimo solicitado. No entanto, encaminhou o processo para análise e aprovação da Assembleia Legislativa. ${ }^{39}$ De seu lado, o presidente do Poder Legislativo acusa a chegada da proposta, ${ }^{40}$ mas a tramitação do processo não avança. Sem resposta imediata, o novo prefeito, Hermógenes Coelho, solicita, via ofício, novas informações a respeito do andamento do pedido feito pelo município. Como não encontramos documentos com resultados definitivos relativos à proposta de empréstimo e contratação da empresa Goianenge, acreditamos que a recusa do empréstimo seja o motivo para que, já no início de 1948, uma nova proposta tenha sido implementada por parte do município.

Em mensagem à Câmara Municipal, Hermógenes Coelho, discursa sobre o "aflitivo problema" "sobejamente conhecido" do acesso à água, "serviço precaríssimo" suprido graças às "mulheres que exercem essa profissão do abastecimento de água da cidade", referindo-se, como seus antecessores, às carregadeiras de água. A pelando para o argumento clássico da ciência à época, afirma não ser "mais possível tolerá-lo numa cidade como a nossa que adquiriu os fóros de civilização por um direito de evolução natural". ${ }^{41}$

\footnotetext{
${ }^{37}$ Idem.

${ }^{38}$ Idem.

${ }^{39}$ Ofício do governador do Estado de Goiás ao presidente da Assembleia Legislativa. Gabinete do Governador. Goiânia, 16 de outubro de 1947. Arquivo Histórico Frei Simão Dorvi (AHFSD).

${ }^{40}$ Ofício do presidente da Assembleia Legislativa de Goiás ao governador do Estado. Assembleia Legislativa. Goiânia, 16 de dezembro de 1947. Arquivo Histórico Frei Simão Dorvi (AHFSD).

${ }^{41}$ Mensagem do prefeito aos membros da Câmara Municipal. Cidade de Goiás, 23 de janeiro de 1948. Arquivo Histórico Frei Simão Dorvi (AHFSD).
} 
Àquela altura, em que pesem as idas e vindas comuns aos processos de negociação e às imposições indissociáveis da burocracia que ainda hoje norteiam a gestão pública no Brasil, as providências para o início das obras já estavam avançadas. Não sem razão, Hermógenes Coelho agradecia ao governador Jeronymo Coimbra a doação de mil e seiscentos metros de canos de ferro destinados à "canalização [da água] que se tem em vista". ${ }^{42}$

\section{Do rio bacalhau aos edifícios da cidade: a canalização da água e a normatização do serviço}

Finalmente, em 27 de janeiro 1948, a Câmara Municipal de Goiás dava autorização para que o prefeito iniciasse as obras de canalização da água na cidade, disponibilizando a quantia de Cr\$150.000,00 cruzeiros através da pasta de "obras públicas". ${ }^{43}$

Dessa forma, na primeira metade de 1948, as obras de canalização da água finalmente foram iniciadas. Em seguida, o prefeito solicita à Câmara uma ampliação do crédito, no valor estimado em $\mathrm{Cr} \$ 300.000,00$. Para que obtivesse sucesso na solicitação, propõe que fosse votada a anulação de verbas destinadas a outros serviços. No dia seguinte, em resposta ao ofício do prefeito, as Comissões de Constituição, Justiça e Redação e de Finanças e Obras Públicas da Câmara Municipal, reiteram, por meio de um parecer, que o Código de Contabilidade da União, em plena vigência, não permitia a abertura de crédito superior à dotação orçamentária de $\mathrm{Cr} \$ 200.000,00$. Sugerem, então, que seja aberto um crédito suplementar e outro especial no valor de $\mathrm{Cr} \$ 100.000,00$ para que o pedido pudesse ser atendido. ${ }^{44}$

Garantida a obtenção dos recursos necessários, em 24 de setembro o município firma contrato com Oliveira Schmaltz, engenheiro residente em Goiânia, para a conclusão das obras. Entre os acordos firmados, o engenheiro deveria concluir a construção da caixa d'água no valor de $\mathrm{Cr} \$ 214.000,00$, cujo pagamento seria realizado em quatro parcelas iguais de $\mathrm{Cr} \$ 53.500,00$, de acordo com o desenvolvimento da obra.

Ao compararmos este contrato com o que fora proposto pela Goianenge, percebe-se muitas alterações, inclusive a própria dinâmica da participação

\footnotetext{
${ }^{42}$ Idem.

${ }^{43}$ Decreto da Câmara Municipal. Sala das Sessões da Câmara Municipal de Goiaz, 27 de janeiro de 1948. Arquivo Histórico Frei Simão Dorvi (AHFSD).

${ }^{44}$ Parecer da Câmara Municipal ao processo autorizando crédito suplementar. Sala das Comissões Reunidas. Cidade de Goiás, 24 de junho de 1948. Arquivo Histórico Frei Simão Dorvi (AHFSD).
} 
da prefeitura no financiamento do projeto. Por exemplo, a proposta anterior englobaria todas as residências públicas, o que demandaria mais materiais e mão-de-obra, o que justificaria a quantia de $\operatorname{Cr} \$ 3.219 .644,40$.

Por outro lado, a leitura da justificativa que integra o documento que solicita o empréstimo de $\mathrm{Cr} \$ 200.000,00$ permite perceber a dificuldade existente em se obter a quantia, o que, provavelmente, levou a prefeitura a contratar apenas um engenheiro e não uma companhia como a Goianenge. Assim, com capacidade de investimento limitada para a implantação do serviço de canalização da água, apenas parcela da população seria contemplada, provocando a exclusão de regiões da cidade e a geração de conflitos com moradores não contemplados.

Com o novo contrato e a conclusão iminente das obras, seria criada uma comissão responsável pela regulamentação da oferta do serviço de abastecimento na cidade, constituída por membros da Comissão de Constituição, Justiça e Redação da Câmara e da Secretaria Municipal de Obras Públicas, como indica ofício do prefeito Hermógenes Coelho. Segundo ele,

Aproximando-se a época em que esta cidade será beneficiada com o serviço de abastecimento d'Agua, marco dos trabalhos que a Prefeitura está realisando com a captação da agua do Córrego "Bacalhau", justo é que nos preparemos para o necessário estudo e elaboração do Regulamento pelo qual se há de reger esse importante serviço. ${ }^{45}$

Assim, em 30 de novembro de 1948, a aprovação do Regulamento pelos poderes municipais e os avanços nas obras, parecem finalmente indicar a chegada da tão sonhada modernização. Trata-se, na verdade, do primeiro regulamento municipal sobre uso da água doméstica da cidade. ${ }^{46}$

O documento está distribuído em dois capítulos. O primeiro versa sobre a distribuição e, sobretudo, dos métodos e condições para que a população tivesse acesso às penas d'água, ${ }^{47}$ recebendo em cada edifício da cidade (nas regiões atendidas) a água oferecida através da canalização subterrânea. Neste documento, fica claro que as despesas de instalação domiciliar da água se-

\footnotetext{
${ }^{45}$ Mensagem do prefeito aos membros da Câmara Municipal. Cidade de Goiás, 23 de janeiro de 1948. Arquivo Histórico Frei Simão Dorvi (AHFSD).

${ }^{46}$ Regulamento do Serviço de Água da Cidade de Goiaz. Sala das Sessões da Câmara Municipal de Goiaz, 30 de novembro de 1948. Arquivo Histórico Frei Simão Dorvi (AHFSD).

${ }^{47}$ Medida usada em abastecimento de água, de diâmetro aproximado ao de uma pena de pato. Orifício colocado para controlar e restringir a pressão e o consumo de água, na entrada da tubulação.
} 
riam cobradas do requerente, a exemplo da caixa de proteção do registro e a disposição dos equipamentos no interior das casas e edifícios.

Nenhuma pena d'água poderia ser instalada sem a autorização do município, devendo os interessados fazer solicitação formal e comprovar a possibilidade de arcar com a quantia da instalação, com o valor mensal de $\mathrm{Cr} \$ 15,00$, além de $\mathrm{Cr} \$ 50,00$ pela ligação. Nos últimos artigos deste primeiro capítulo do Regulamento o legislador alerta quanto às ligações clandestinas que, caso descobertas, teriam o registro da residência fechado e imposição de multa no valor de $\mathrm{Cr} \$ 200,00$.

O segundo capítulo trata das disposições gerais, onde são especificadas multas em caso de atraso no pagamento, gestão irregular dos registros, uso da água para abastecimento de terceiros, como também “àqueles que obstruírem mananciais, danificar caixas, canos ou de qualquer forma impedir o funcionamento da canalização".

Assim, se os procedimentos de encanamento da água permitiram, por um lado, a criação e imposição de um novo sistema normativo, introduzindo obrigações antes inexistentes na rotina dos habitantes, permitiria, por outro lado, a realização de um sem número de atividades domésticas que antes dependiam diretamente de seu transporte em latas a partir dos vários chafarizes da cidade. Neste contexto, o poder público municipal, a fim de garantir o bom andamento dos serviços, orientava a população a respeito da aplicação de multas caso algum dos termos contratados fossem quebrados.

No início de 1949, no dia 11 de abril, o jornal Cidade de Goiás celebrava a conclusão das obras de canalização, fazendo referência à "obra de vulto" que "há anos Goiás necessitava: - a água encanada". De acordo com o jornal,

Veio, em 1946, a campanha para a eleição de Governador do nosso Estado e, em praça pública, o candidato Dr. Jeronymo Coimbra Bueno promete que, se eleito, faria o Estado cumprir os seus compromissos com a velha cidade de Goiaz. Consumou-se sua eleição e a promessa feita está sendo cumprida. Encontramos em S. Excia. Um devotado amigo de nossas causas pronto a ajudar-nos a resolver nossos problemas [...] com o apoio encontrado do sr. Governador, poude o sr. Hermógenes Ferreira Coelho, Prefeito Municipal, realizar esta obra de vulto de que há anos Goiás tanto necessitava: - a água encanada em nossos lares, de cuja importância ninguém ignora. ${ }^{48}$

${ }^{48}$ O Município de Goiás e o Governo Coimbra Bueno. Jornal Cidade de Goiaz. Cidade de Goiás, ano 10, n. 382, 11 abr. 1949. Arquivo Histórico Frei Simão Dorvi (AHFSD). 
De fato, toda a saga para a realização das obras de encanamento durou mais de cinco décadas. Assim como as críticas e as denúncias, os esforços e as tratativas visando modernizar a oferta do serviço finalmente chegava a seu termo. Em Goiás, desde os tempos da ruptura introduzida pelo golpe de 1930, diferentes discursos trataram do assunto, modulados pela perda do título de capital. Contudo, ao sabor das circunstâncias, o projeto fora sempre abortado.

É em 1949, portanto, que o novo sistema de abastecimento dá início a um lento processo de transformação do uso da água, marcando, sobretudo, a natureza de seu controle e distribuição: de acesso público, captada livremente nas fontes, poços e chafarizes, à condição de objeto e produto submetidos à autoridade do poder público, cujo acesso impunha novas formas de normatização por meio de uma economia associada ao seu consumo.

Assim, rapidamente chegavam à prefeitura dezenas de solicitações para ligação de penas d'água. Muito embora a maioria da população ainda se abastecesse das águas dos chafarizes, parte importante dos habitantes adaptava suas residências para a chegada da água encanada. Para Souza (2012), desde então, a partir do sistema de encanamento subterrâneo, o ofício das carregadeiras d'água seria silenciado pela modernização, permanecendo, desde então, no único lugar aceitável ante as transformações da história nos espaços da memória da cidade. Simbolicamente, constituindo parte da tradição local, este ofício seria associado ao passado.

De outra parte, a modernização que chegava por meio de encanamentos subterrâneos alimentava as expectativas há muito associadas aos discursos das autoridades públicas. Não sem razão, em mensagem à Câmara Municipal, o prefeito informava que a cidade deixaria para trás o "flagelo das secas", indicando a chegada de um tempo em que a água jorraria "abundantemente, nas residências particulares". Segundo ele, "Ela jorra, hoje, abundantemente, nas residências particulares, nos quartéis, nos hospitais, hotéis, bares, enfim, nos pontos mais longínquos da cidade". ${ }^{9}$

\section{Entre a água encanada e os antigos chafarizes: expansão e limites do sistema de abastecimento}

Em 1951, um relatório do encarregado dos serviços de abastecimento d'agua da Cidade de Goiás, Francisco Cardoso Amaral, permite conhecer as condições de funcionamento do novo sistema durante os anos de 1949-51 e,

${ }^{49}$ Mensagem do prefeito à Câmara Municipal. Goiânia: Tipografia Popular. 1950. Arquivo Histórico Frei Simão Dorvi (AHFSD). 
sobretudo, as novas ramificações dos encanamentos na dinâmica urbana da cidade. Em janeiro de 1949, a prefeitura municipal estabelecera contrato com o próprio Cardoso Amaral visando a realização de serviços para a expansão do sistema de abastecimento de água. Neste documento, o autor lembra que o contrato estaria próximo de expirar e que não desejava mais exercer aquela função. Além disso, de acordo com ele, teria elaborado o relatório em função de uma "celeuma" ocorrida durante o último "período de longa estiagem", por haver faltado água "principalmente em ruas situadas nas partes mais elevadas" da cidade. Em suas palavras,

Boatos e mais boatos, os mais desencontrados, fazem-se ouvir. Não seria lógico, é evidente, ficássemos calados, sem proporcionar-lhe informações e dados precisos, reunidos em um documento, com o qual essa Prefeitura, ao par de toda a realidade, pudesse adotar as providencias julgadas necessárias. ${ }^{50}$

Elencando as obras realizadas durante a vigência de seu contrato, Cardoso Amaral menciona que havia no sistema de abastecimento vários problemas e que muitos teriam sido resolvidos durante sua gestão. Segundo ele, "No decorrer do nosso primeiro ano de trabalho, conforme passaremos a demonstrar, muito tivemos que fazer no sentido de melhorar - corrigindo falhas que seriam notadas mesmo pelos que nada entendessem do assunto". ${ }^{1}$

Entre as melhorias apresentadas o encarregado indicava a modificação completa do sistema de captação do Bacalhau, assim como a de outros veios d'água como o Quatí, Pará e Mangueira que, de acordo com ele, resolveria o problema do abastecimento, pois permitiria o aumento do volume durante os períodos de seca. Teria havido ainda melhoramentos tanto na linha adutora como na caixa de armazenamento, além de ter sido ele o responsável pela instalação de 6.528 metros de canos no perímetro urbano, contra apenas 2.314 realizados por seu antecessor, o engenheiro Oliveira Schmaltz. "Temos assim", nos termos de Cardoso Amaral, "[...] na data em que confeccionamos o presente [relatório], um total de 8.842 metros colocados sob o solo de nossa urbs, levando agua potável a 568 residencias, sendo [que] desse total, 74\% - em número arredondado - foram por nós assentados a partir de janeiro de $1949 .{ }^{52}$

\footnotetext{
${ }^{50}$ Relato do encarregado dos serviços de abastecimento d'água ao prefeito municipal. Cidade de Goiás, 10 de novembro de 1951. Arquivo Histórico Frei Simão Dorvi (AHFSD).

${ }^{51}$ Idem.

${ }^{52}$ Idem.
} 
Entre as observações levantadas por Cardoso Amaral, destaca-se o número de penas d'agua "excessivas", responsável pela escassez de água em alguns pontos da cidade. Como bem lembrou, o primeiro engenheiro, Oliveira Schmaltz, construiu o serviço estimando oferecer 500 penas d'água, mas, de acordo com sua análise, poderia oferecer o produto a até 650 residências sem prejudicar o fornecimento de água. Até o final de 1951, a prefeitura havia registrado o total de 568 ligações. No entanto, Cardoso Amaral denunciava a existência "[...] em funcionamento [de] mais de 1.000, sem que o pagamento correspondente seja efetuado, equivalendo dizer que $50 \%$ das penas funcionam clandestinamente. O pior, entretanto, é que isso é do nosso conhecimento e não temos meios para coibir esse abuso". ${ }^{53}$

Além disso, continua, "É certo que todos os consumidores querem água em abundância nas torneiras", contudo, "Poucos são os que constroem a caixa; a maioria evita essa despesa recorrendo à violação das penas. Alguns há que as retiram e ligam diretamente o próprio cano", concluindo que muito ainda faltava para que o sistema funcionasse com a eficácia desejada. ${ }^{54}$

De fato, Cardoso Amaral parecia conhecer do assunto. Embora aclamada pela mídia e pela população, não tardou que os problemas na estrutura de distribuição de água começassem a surgir. Provavelmente, como denunciado no relatório, as causas poderiam ser encontradas nos materiais de qualidade ruim e nos serviços realizados de forma inadequada, ocorrendo desde problemas de perda de água pelo canal até o volume insuficiente para atender a sempre crescente demanda.

Desta forma, o serviço de abastecimento de água se provou cheio de problemas, além de não atender grande parte da população que habitava em áreas mais afastadas e distantes da região central da cidade. Assim, a ampliação do número de requerimentos para que o serviço alcançasse bairros e ruas não contemplados pressionava o poder público e a incapacidade de fornecer água encanada a todas as residências conduziu a outra estratégia: a construção de novos chafarizes que, àquela altura, já pareciam ultrapassados, ao menos nos discursos oficiais. O retorno, ainda que parcial, ao antigo sistema denunciava a dimensão dos problemas que envolviam a distribuição e o abastecimento de água, muito presentes até a década de 1950.

Em 1954, em requerimento encaminhado segunda vez ao presidente da Câmara Municipal, o vereador Sebastião Veloso insistia na necessidade

${ }^{53}$ Idem.

${ }^{54}$ Idem. 
de interceder junto ao prefeito municipal solicitando a construção de novos chafarizes que atendessem a população "pobre" da cidade. Nos termos do requerimento,

[...] que fosse instalado um Chafariz no alto da Rua Ernestina; dito melhoramento vira beneficiar os pobres operários da Rua Oriente, da Damiana, etc., sendo que ate esta data, não foi instalado o referido chafariz, trazendo com isto, serias dificuldades aos inúmeros moradores pobres daquela zona da cidade, que atualmente carregam aquele precioso líquido, em latas, na cabeça, como se morassem no deserto do Saara. [...] Acredito que se este chafariz não foi instalado, por ser aquela parte da cidade, habitada por gente pobre; se fosse em outro setor, onde residissem, tubarões e manatas, já o teriam instalado, de há muito. Aproveito a oportunidade para requerer a instalação de outro chafariz, no alto do Moreira. Ditos chafarizes deverão ser instalados com critério e não como no caso das décimas, que para os ricos, o aumento foi diminuto, enquanto que para os pobres foi excessivo, devido aos lançamentos que foram feitos sem critério e por pessoas incapazes. Espero não ser preciso importunar pela TERCEIRA VEZ, com tal pedido. ${ }^{55}$

Interessante notar que ainda na década de 1950, enquanto as cidades brasileiras ampliavam a oferta de água encanada nos espaços urbanos, brotavam em Goiás propostas para a construção de chafarizes. Enquanto os investimentos públicos destinados ao serviço beneficiavam áreas urbanas específicas, a ampliação do sistema de canalização excluía parte importante dos moradores, o que, inclusive, interferia em outras questões, a exemplo estratégica valorização imobiliária de setores beneficiados pela oferta do serviço em detrimento de outras partes da cidade.

Em seu requerimento, Sebastião Veloso colocava em evidência aspectos econômicos e sociais ligados aos limites do sistema de distribuição, circunscrito aos mais abastados e aos residentes de setores privilegiados, enquanto os mais pobres, habitantes das zonas periféricas da cidade, não tinham acesso sequer ao antigo método de distribuição: os chafarizes.

Ante os problemas apresentados, os gestores municipais eram pressionados a investir de forma permanente na ampliação do sistema, ainda que envoltos em uma dificuldade recorrente: a parca disponibilidade de recursos.

\footnotetext{
${ }^{55}$ Requerimento do vereador Sebastião Veloso ao presidente da Câmara Municipal. Cidade de Goiás, 3 de maio de 1954. Arquivo Histórico Frei Simão Dorvi (AHFSD).
} 
Assim, desde 1953, prefeitura e câmara se mobilizavam em torno de um empréstimo de $\mathrm{Cr} \$ 8.000 .000,00$, solicitado à Caixa Econômica Federal.

Três anos mais tarde, em meio às dificuldades financeiras, o prefeito do município solicitava à Câmara Municipal autorização para convênio com a União, por intermédio do Ministério de Viação e Obras Públicas (MVOP), visando a reparação da rede de distribuição de água e a construção de uma rede de esgoto sanitário. ${ }^{56}$ Autorizado o convênio, apenas em 1961 seria firmado contrato com o Departamento Nacional de Obras de Saneamento (DNOS), órgão do MVOP. Na prática, a responsabilidade pelos serviços de abastecimento de água e esgoto havia sido transferida, por meio de concessão municipal, para o Estado, dando origem, em 1967, à Companhia Saneamento de Goiás (SANEAGO).

\section{Conclusão}

A experiência das autoridades municipais, bem como a expectativa e a demanda dos habitantes da Cidade de Goiás quanto aos procedimentos de canalização da água indicavam a necessidade de sujeitá-la ao controle dos homens e submetê-la aos interesses dos agentes que governavam a cidade. Redefinindo normas e valores, seus discursos e suas práticas impunham um exercício de dominação da natureza frente às novas exigências trazidas pela modernidade. A tentativa de produzir um espaço urbano moderno trazia consigo a imposição de novos hábitos e novos direitos. Desde logo, as "condições dificílimas" e os "processos primitivos de abastecimento", "anti-higiênicos", denunciados nos discursos da Câmara Municipal, seriam coisas do passado.

Por meio de estudos técnicos, procedimentos políticos e tratativas econômico-financeiras foi inaugurado, em 1949, o serviço de abastecimento doméstico de água, celebrado nos jornais e, sobretudo, no discurso político. Contudo, a estrutura inicial não atendia plenamente as expectativas da população. Durante os primeiros anos, apenas uma pequena parcela das residências teve acesso ao serviço, restrito à população abastada e aos moradores de setores privilegiados da cidade.

Se o custo reduzido da implantação inicial do sistema condicionava e limitava a oferta do serviço, os anos que se seguiram foram palco de embates

\footnotetext{
${ }^{56}$ Mensagem do prefeito municipal à Câmara Municipal da Cidade de Goiás solicitando autorização para realização de convênio com o Ministério de Viação e Obras Públicas para construção da rede de água e esgoto da cidade. Cidade de Goiás, $1^{\circ}$ de novembro de 1956. Arquivo Histórico Frei Simão Dorvi (Fundação Educacional da Cidade de Goiás).
} 
em torno da ampliação do acesso à água encanada para toda a população. Conforme demonstra a documentação, a obrigatoriedade do pagamento pela instalação das penas d'água, bem como o peso de uma taxa mensal de consumo, induziu moradores ao recurso das ligações ilegais. Por outro lado, como nem todos puderam desfrutar de imediato da água encanada, fontes e chafarizes continuaram abastecendo a população da cidade.

Embora os chafarizes e as fontes representem uma herança colonial na história de Goiás, não houve de fato uma ruptura imediata entre este modelo e o da água encanada. Durante a década de 1950, perdurou na antiga capital um padrão centrado em um abastecimento múltiplo: um modo de acesso à água público e gratuito e um sistema pago, privado e doméstico.

A ocasião para uma ruptura demandaria tempo. Se os chafarizes, localizados em praças públicas, constituíam-se em espaços tradicionais sociabilidade, aos poucos, devido à implementação cada vez mais vasta da técnica de distribuição baseada em redes subterrâneas, o que antes era visível, tornava-se, pouco a pouco, invisível. Nesse processo, fontes e chafarizes, enquanto representações de um passado não tão distante, tornavam-se, paulatinamente, objetos de caráter simbólico e ornamental, dissipando e desvanecendo a tradição de personagens tão comuns no cotidiano da cidade quanto os carregadores de água, personificados, em Goiás, na imagem de Maria Macaca, mulher negra eternizada pelo seu ofício de transportar água em latas na cabeça.

Tal imagem desaparecia lentamente na antiga capital que a passos lentos caminhava em direção ao aspirado e ambicionado progresso. Desde então, os marcos da modernidade e as contradições que a acompanham, estariam associadas aos canais subterrâneos, invisíveis, que transportavam as águas do Rio Bacalhau aos espaços de consumo domésticos da Cidade de Goiás.

\section{Referências}

ALBERNAZ, Ondina de Bastos. Reminiscências. Goiânia: Kelps, 1992.

BOSI, Antônio. “As águas das cidades (1850-1920): usos e negócios”. Revista História e Perspectivas, v. 1, n. 36-37, p. 109-132, 2007.

BRUNI, José Carlos. “A água e a vida”. Revista Tempo social, v. 5, n. 1-2, p. 53-65, 1993.

CHAUL, Nasr Fayad. Caminhos de Goiás: da construção da decadência aos limites da modernidade. Goiânia: Editora UFG, 2001. 
CIDADE DE GOIÁS. Decreto da Câmara Municipal. Sala das Sessões da Câmara Municipal de Goiaz, 27 de janeiro de 1948. Arquivo Histórico Frei Simão Dorvi (AHFSD).

JORNAL CIDADE DE GOIAZ. O Município de Goiás e o Governo Coimbra Bueno. Cidade de Goiás, ano 10, n. 382, 11 abr. 1949. Arquivo Histórico Frei Simão Dorvi (AHFSD).

MENSAGEM. Prefeito à Câmara Municipal. Goiânia: Tipografia Popular. 1950. Arquivo Histórico Frei Simão Dorvi (AHFSD).

MENSAGEM. Prefeito aos membros da Câmara Municipal. Cidade de Goiás, 23 de janeiro de 1948. Arquivo Histórico Frei Simão Dorvi (AHFSD).

MENSAGEM. Prefeito municipal à Câmara Municipal da Cidade de Goiás solicitando autorização para realização de convênio com o Ministério de Viação e Obras Públicas para construção da rede de água e esgoto da cidade. Cidade de Goiás, $1^{\circ}$ de novembro de 1956. Arquivo Histórico Frei Simão Dorvi (Fundação Educacional da Cidade de Goiás).

MONTEIRO, Ofélia Sócrates do Nascimento. Reminiscências: Goiás de antanho. 1907 a 1911. Goiânia: Oriente, 1974.

OFícIO. Comandante do quartel da Polícia Militar do Estado de Goiás ao prefeito municipal da Cidade de Goiás. Goiânia, 29 de maio de 1937. Arquivo Histórico Frei Simão Dorvi (AHFSD).

OFíCIO. Diretor comercial da Sociedade Goiana de Engenharia ao prefeito municipal da Cidade de Goiás. Goiânia, 10 de setembro de 1946. Arquivo Histórico Frei Simão Dorvi (AHFSD).

OFíCIO. Diretor comercial da Sociedade Goiana de Engenharia ao prefeito municipal da Cidade de Goiás. Goiânia, 25 de setembro de 1946. Arquivo Histórico Frei Simão Dorvi (AHFSD).

OFícIO. Diretoria do Serviço Sanitário do Estado de Goiás ao prefeito municipal da Cidade Goiás. Goiás, 7 de novembro de 1932. Arquivo Histórico Frei Simão Dorvi (AHFSD).

OFícIO. Governador do Estado de Goiás ao presidente da Assembleia Legislativa. Gabinete do Governador. Goiânia, 16 de outubro de 1947. Arquivo Histórico Frei Simão Dorvi (AHFSD). 
OFÍCIO. Prefeito municipal ao diretor do Departamento Estadual das Municipalidades. Goiás, 28 de setembro de 1946. Arquivo Histórico Frei Simão Dorvi (AHFSD).

OFícIO. Prefeito municipal ao diretor do Departamento Estadual das Municipalidades. Goiás, 10 de outubro de 1946. Arquivo Histórico Frei Simão Dorvi (AHFSD).

OFÍcIO. Prefeito municipal da Cidade de Goiás, João Coutinho, ao diretor do Departamento Estadual das Municipalidades, José de Assis Moraes. Goiás, 2 de setembro de 1947. Arquivo Histórico Frei Simão Dorvi (AHFSD).

OFíCIO. Presidente da Assembleia Legislativa de Goiás ao governador do Estado. Assembleia Legislativa. Goiânia, 16 de dezembro de 1947. Arquivo Histórico Frei Simão Dorvi (AHFSD).

OLIVEIRA, Eliézer Cardoso. "As tragédias como evento hermenêutico: as enchentes do Rio Vermelho na Cidade de Goiás”. Revista História e Cultura, v. 3, p. 306-324, 2014.

PARECER. [Goiás do Couto, Fritz Koeller e Humberto Rizzo] sobre proposta para a execução dos serviços de abastecimento de água potável. Cidade de Goiás, 4 de agosto de 1947. Arquivo Histórico Frei Simão Dorvi (AHFSD).

PARECER. Câmara Municipal autorizando crédito suplementar. Sala das Comissões Reunidas. Cidade de Goiás, 24 de junho de 1948. Arquivo Histórico Frei Simão Dorvi (AHFSD).

PROPOSTA. Diretoria da Goianenge para execução do serviço de água potável para a Cidade de Goiás. Goiânia, 29 de julho de 1947. Arquivo Histórico Frei Simão Dorvi (AHFSD).

REGULAMENTO. Regulamenta serviço de água na Cidade de Goiaz. Sala das Sessões da Câmara Municipal de Goiaz, 30 de novembro de 1948. Arquivo Histórico Frei Simão Dorvi (AHFSD).

RELATO. Encarregado dos serviços de abastecimento d'água ao prefeito municipal. Cidade de Goiás, 10 de novembro de 1951. Arquivo Histórico Frei Simão Dorvi (AHFSD).

REQUERIMENTO. Vereador Sebastião Veloso ao presidente da Câmara Municipal. Cidade de Goiás, 3 de maio de 1954. Arquivo Histórico Frei Simão Dorvi (AHFSD).

ROCHE, Daniel. História das coisas banais: nascimento do consumo nas sociedades tradicionais (XVII-XIX). Lisboa: Editorial Teorema, 1998. 
SANT’ANNA, Denise Bernuzzi. “A conquista da água”. Revista Projeto História. São Paulo, v. 18, p. 295-300, 1999.

SOUZA, Rildo Bento de. A História não perdoa os fracos: o processo de construção mítica de Pedro Ludovico Teixeira. 2015. 269 f. Tese (Doutorado em História) - Universidade Federal de Goiás, Goiânia, 2015.

Artigo recebido para publicação em 09/06/2020 Artigo aprovado para publicação em 16/02/2021 